\title{
The Syrian Crisis and International Security
}

Raymond Hinnebusch

In Myriam Dunn Cavelty and Thierry Balzacq, Routledge Handbook of Security Studies, $2^{\text {nd }}$ Ed, 2017

The crisis in Syria has been widely recognized as constituting a multi-dimensional threat to international security. It is seen as a humanitarian crisis, a breeding ground of transnational terrorism, a site of the use of WMDs and as a failed state. Some see it as a turning point in which the 'responsibility to protect' civilians was abdicated by the international community. It can also be seen as a new site to understand the conduct of 'New Wars,' and of insurgency and counter-insurgency, as this chapter proposes. The intractability of the conflict is a challenge to our thinking on conflict resolution and the conduct of diplomacy to address internal wars. The conflict has been a site of vociferous debates among theorists and practitioners over how the international community should respond (Kaldor 2013, Falk 2014).

This chapter has five parts. In the first, the context and roots of the conflict are introduced. It explains why the non-violent resistance paradigm failed to predict the dynamics of the Syrian uprising and shows that in the Syrian case, the conflict was first about (economic) class grievances and only then turned into a sectarianized conflict. In the second, the Syrian conflict is looked at through theories of 'New Wars' (Kaldor 1999) and insurgency and counter-insurgency. In the third, the dynamics of violence are described, first by looking at human security vs. state security, and then by focusing on the responsibility to protect-norm and its influence on the conflict. The fourth section, of the chapter looks at the obstacles to a diplomatic resolution of the conflict. The conclusion considers the implications of the Syria conflict for security theory and practice.

\section{CONTEXT AND ROOTS OF THE CONFLICT}

\section{State-Building Dilemmas}

The Syria crisis is ultimately rooted in what Ayoob (1995) called the 'Third World security predicament'. This signifies the challenge of $20^{\text {th }}$ century state developers who undertake primitive power accumulation in a world in which populations have much greater demands for participation and welfare in comparison to earlier times; and also when the violent methods of earlier state builders (e.g. see Tilly 1985), are no longer seen as legitimate. This Third World security predicament is exacerbated in the case of Syria and its state building dilemmas. The starting point for the current crisis can be traced back to the post-WWI imposition of a system of states in the region in what David Fromkin (1989) called a 'peace to end all peace.' The Levant states, artificially created by Western imperialism in violation of the dominant identities of the region's peoples, had to compete with powerful sub- and supra-state forces for the loyalties of their populations, and hence suffered built-in legitimacy deficits, which made them more likely to fail. 
In these circumstances, Arab state builders gravitated toward neo-patrimonial practices that combined time-honoured indigenous state-building formulas--Ibn Khaldun's assabiya or elite solidarity built on primordial ties--with modern bureaucratic and security machinery, coupled with surveillance technology. This formula was empowered, beyond its 'shelf life,' by the exceptional availability of hydrocarbon and geopolitical rent in the region. It enabled the lubrication of clientele networks supportive of neo-patrimonial rule and for a period enabled a populist 'social contract' with the masses.

Ba'thist populist authoritarianism in Syria was no exception: Hafiz al-Asad established a regime that combined reliance on the assabiya of his Alawi followers - who he appointed to strategic commands of the military-security apparatus; rent-fuelled clientelist co-optation of a cross-sectarian coalition of Ba'thi politicos and Sunni business elements; and mass incorporation through the Ba'th party of the stateemployed middle class, trade unionists and big segments of the peasantry (via land reform). This regime was legitimized by Arab nationalist ideology and defended by the repression of persistent (mostly Islamic) opposition.

Yet each ingredient of this state building recipe had its costs: sectarian assabiya alienated out-groups; rent was finite and its decline enervated co-optative capability; repression left many politically unincorporated; and legitimation from Arab nationalism embroiled Syria in costly regional conflicts and generated Western hostility, which became particularly dangerous once Asad lost his Cold war era Soviet patron. Furthermore, relying on sub-state (Alawi) and supra-state loyalties (Arabism) deterred consolidation of identifications with the Syrian state itself (Hinnebusch 2001).

Across the region, a combination of rent decline and population boom created economic crises that put extreme pressures on the authoritarian republics to move toward what might be called 'post-populism'. In post-populism, the state withdraws from welfare provision and favours investors, thereby creating a new crony capitalism and exacerbating social inequality. Twin global forces exacerbated the situation: neo-liberal globalization, as manifested in the International Monetary Fund (IMF)'s 'structural adjustment' campaigns, reduced the capacity of the oil-poor authoritarian republics to materially satisfy mass constituencies. In parallel, the global diffusion of internet technology -- and with it, West-centric democratization discourses -- helped to delegitimize authoritarian post-populist ruling formulas (Hinnebusch 2012). In Syria, the younger Asad's post-populism sowed the seeds of the Syrian Uprising and the subsequent protracted conflict.

\section{From Non-Violent Protest to the Domestic Security Dilemma}

According to the mass non-violent protest paradigm (Stephan and Chenoweth 2008), mass protest can rapidly and effectively destabilize authoritarian regimes; even if the regime refuses protestors' demands and uses violence against them. The literature predicts that use of violence is likely to backfire, since it stimulates wider anti-regime mobilization, triggers international sanctions and support for the opposition, and most importantly, causes defections in the security forces, which will be reluctant to use violence against fellow citizens who are not, themselves, using violence. This scenario could have been part of the calculations of the Syrian protestors who, in large numbers, 
took on the regime after March 2011. The outcome, however, was neither democratic transition, revolution nor effective repression, but stalemated semi-sectarian civil war. It was not inevitable that the Syrian Uprising would descend into sectarian civil war; so what went wrong?

Security studies have increasingly focused on the causes of internal wars like Syria's. Studies of communal (ethnic and religious) conflict are differentiated between 'essentialists' that see ancient hatreds as rooted in history, and 'instrumentalists' who see these hatreds stirred up by leaders or their opponents (Kaufman 2008: 203-04). Syria comes much closer to the latter model. As a fragmented state composed of many religious and ethnic minorities, artificially constructed by Western imperialism and with a fragile sense of shared identity, Syria had built-in vulnerabilities. The regime's use of sectarian solidarity assabiyya had also created resentments among the majority Sunni population while the minority but politically-dominant Alawis had a strong sense of insecurity rooted in the previous Islamic fundamentalist insurgency of the 1980s that played on sectarian differences (Goldsmith 2011).

Still, Syria's sects did not hate each other. In fact, considerable intermarriage and intersectarian business alliances were evident in the 2000s. The Alawi-led ruling coalition had long included many of the Sunni majority (and still does) and had built an alliance with the Sunni dominated business class. Rather than being chiefly an issue of sectarian politics, the conditions for the revolt were prepared by the regime's turn to neo-liberal policies, marginalizing its formal rural constituency and promoting the unequal enrichment of urban-based crony capitalists. The main grievances were economic initially: the conflict was about class and urban-rural cleavages. The discourse of the protestors was secular, inclusive and cross-sectarian, although a perception of favouritism in access to opportunity gave a sectarian edge to socio-economic grievances.

Once the opposition was able to flood the streets with interminable protests, the regime found itself on the defensive--as in the non-violent protest paradigm. But why did this not create the conditions for a democratic transition? While the mass non-violent protest paradigm gives little attention to the dynamics of such a transition, democratization studies suggest (O'Donnell and Schmitter 1986) that non-violent protest is only likely to lead to a peaceful transition if a coalition between soft-liners in the regime and in the opposition manages to marginalize the hardliners (as happened, in some respects, in Tunisia and Egypt). In the Syrian case, however, the soft-liners were marginalized on both sides.

Asad's choice to respond to the demonstrations with a 'security solution' rather than democratic reforms was decisive: in standing with regime hardliners, he empowered the hardliners in the opposition as well. In resorting to a sectarian discourse against 'terrorism' and increasing state violence against opponents, Asad helped turn peaceful protests into violent sectarian conflict. Equally important were the maximalist demands of the opposition: the removal of the regime. Arguably, the mistake of the Syrian protest movement was its 'rush to confrontation' with the regime while the latter still retained significant support (cf. Mandour 2013). With the hardline opposition insisting on the fall of the regime and resorting to periodic violence, the soft-liners in the regime were 
unlikely to marginalize the hardliners. Senior soft-liners, who spoke the language of reconciliation, seemed too far from the immediate levers of repression, which were in the hands of hardliners such as Maher al-Asad (Harling 2011). Similarly, internal third parties who tried to mediate were squeezed out, notably the traditional opposition organized in the National Coordination Committee (NCC), whose members were much more experienced than the younger demonstrators. At the famous Samiramis conference in June 2011 they put forth a compromise proposal - but both regime and opposition rejected it.

Even though the regime conceded many reforms that the opposition had been demanding for decades and proposed dialogue, those committed to its removal dismissed these initiatives as inadequate and insincere. Besides the moral outrage at the killings perpetuated by the government, opposition activists believed that they could only be safe if the regime was totally destroyed since it would be certain to seek retribution if it survived. The fragmented and localized opposition also lacked credible leaders who could deliver its consent to a negotiated settlement should that have appeared in its interest. With regime concessions being 'too little too late', the opposition escalated its resistance via ever larger mass demonstrations which in turn provoked violent and repressive counter-escalation by the regime.

But why did mass protest not lead to forced presidential departure, as in Egypt and Tunisia, or, if not that, then regime collapse amidst revolution from below? The President's political and clientele ties reached too deeply into the security apparatus to separate it from him as had happened in the former Arab countries - and many of the elites around him, seeing the regime and their interests in jeopardy were prepared to use violence against protestors. While the Asad regime's increasing use of lethal force against non-violent protestors did alienate wide swaths of the public (as the non-violent resistance paradigm expects), the opposition could be constructed, among the regime's constituency, as a jihadist 'other', because society rapidly became communally polarized.

As for the many Syrians caught in the middle, especially the upper and middle classes, the regime's claim to defend order against the disruption unleashed by the Uprising caused a significant portion of them to see it as the lesser of two evils. This was all the more the case once radical Islamists, and especially al-Qaida-linked jihadists, assumed a high profile within the opposition and as the opposition itself fragmented into warring camps. Unable to quickly separate the regime from its backers, the opposition sought to de-stabilize the regime through interminable mass civil unrest, in order to provoke defections from the security forces, undermine the economy, and break the regime alliance with business. For this strategy to succeed, it was necessary that external constraints deter full-scale regime repression or else that such repression would provoke outside intervention. The regime, however, was not deterred by fear of intervention from resorting to a 'military solution' that did not spare civilians. This hastened Sunni defections from the army - specifically to the anti-regime 'Free Syrian Army' - and later encouraged the rise of jihadists, leading to the militarization of the Uprising. By infiltrating and seizing half of Aleppo in 2012, the opposition gave reason for the regime to resort to air and artillery attacks on urban built up areas. 
In parallel, it was the instrumentalization of sub- and trans-state identities by political entrepreneurs that turned what was initially a largely urban-rural and class conflict into a sectarian one: it was the Asad regime's securitization of peaceful protest by depicting it as Sunni Islamist terrorism that rallied the Alawi community and other minorities to the regime and led to the opposition's later turn, in response, to Sunni Islamist jihadism. As order broke down, the 'security dilemma' kicked in and each side resorted to defensive tactics that made both feel more insecure (Posen 1993). Extremists who advocated pre-emptive violence against other communities were empowered and people began to be treated according to their communal identity. In fact, something approaching ethnic cleansing took place in certain mixed areas, although it was not widespread and elsewhere heterogeneity increased-with e.g. an influx of Sunni refugees to the Alawi heartland in the west. Hatred and fear of the 'other' spread the conviction on both sides that no political solution was possible, even when it became clear that neither could defeat the other. Overall, the Syrian case validates the instrumentalist view of communal internal wars--that it is political entrepreneurs, not ancient hatreds--that make for conflict. In the Syrian case it was the regime, but also the opposition and external powers later, that sectarianized a conflict that was initially about class grievances.

This outcome is quite at odds with the non-violent resistance paradigm in which an authoritarian regime's violence progressively isolates itself from the vast majority of the population, precipitating its collapse. This distinguishes Syria from Tunisia and Egypt where the incumbent presidents proved unable to get the army to repress mass protest survive, thereby enabling a potential democratic transition. This points to the fact, ignored by the resistance paradigm, that differences in the social composition of authoritarian regimes make for important variations in their vulnerability to revolt against it. In more homogeneous societies such as Egypt and Tunisia, mass anti-regime mobilization is likely to be much more thorough and decisive than in communally divided ones like Syria; and where the presidency's ties to the military are stronger and the army's institutional autonomy weaker, the military is far less likely to jettison a president to save itself. What the non-violent protest paradigm also fails to anticipate is the consequences of mass protests that destabilizes the state but fail to lead to democratic transition. The outcome may well be a failed state, a Hobbesian world in which life becomes 'nasty, shortish and brute' and which may be very difficult to reverse. This happened in Syria.

\section{NEW WARS, COUNTER-INSURGENCY, FAILED STATES AND TERRORISM}

The intractability of the Syrian conflict betrays symptoms of Mary Kaldor's (1999) 'New Wars.' In her scenario, state weakening empowers transnational non-state actors engaged in identity wars and ethnic cleansing, in which the distinction between combatants and non-combatants breaks down. All the symptoms she describes are present in the Syrian case: As the normal economy collapsed, a 'war economy,' in which people deprived of a normal life and income sought survival through spoils and flocked to militant groups with access to largely external funding, gave extra life to the conflict despite the damage it was already inflicting on all sides. Warlordism filled the security gap as rival factions arose across opposition-controlled areas. Trans-state refugee flows, funding by Diasporas and identity groups crossing borders, and 
transnational arms trafficking embedded the conflict in wider regional struggles that made it all the harder to resolve.

Such wars spill over to the neighbours where insurgents may enjoy safe havens. In the case of Syria, this happened with Turkey, who harboured and encouraged anti-regime rebels (Schanzer and Tahiroglu 2014). Large parts of the Syrian population, caught between the warring sides, were displaced internally or fled to neighbouring countries and beyond. The spill-over of the conflict impacted negatively on the security of Syria's neighbours (Turkey, Lebanon and Jordan), with multi-sectarian Lebanon particularly at of risk being drawn into it, especially after the Lebanese Hizbollah intervened in Syria on the regime side, thereby inflaming anti-Shia sentiment among Lebanese Sunnis. These states also carried a heavy budget burden for refugee support, creating resentment among their populations against Syrian refugees. Furthermore, the negative impact of protracted conflicts on economic development in border states is well-documented (Lambach and Debiel 2010: 164).

The Syrian case throws light on theories of insurgency and counter-insurgency as well. As Speers indicates (2008), insurgents traditionally seek to be the fish in the water of the population, living off their support. This has been the case in rebel dominated areas of Syria, but increasingly, the insurgents also live on outside funding that enables them to co-opt elements of the population. Their embedding in the population gave them such wide support that it was impossible for the Syrian regime to crush them. This and outside arming by rival regional and global powers enabled them to wrest large parts of the country from government control. Their main weakness, however, was their extreme fragmentation and extensive intra-opposition fighting, which put an end to the momentum that seemed to be on their side in 2012 and somewhat re-tilted the balance toward the regime in 2013.

The regime's counter-insurgency methods are identified as 'traditional tactics' (Speers 2008), which includes securing base areas first. It managed to consolidate relative control over its heartland, running from Damascus northward via Homs and Hama to the coastal provinces where the Alawi community is located. In doing this, the regime resorted to starving out insurgents by food control and blockading villages. Theorists claim (Spear) that counter-insurgency is most successful if it is made up by $80 \%$ political and $20 \%$ military methods, with a discriminating and well-targeted use of force, since the government needs to win over the less committed insurgents in order to isolate the hard-core opposition. However, in case the priority is put on protection of counter-insurgency forces instead of protection of the population, then firepower and airpower will be maximized regardless of collateral damage and political costs. Such firepower is particularly unsuited to urban warfare where recent insurgencies, including Syria's, have been fought. In Syria, the demographic disadvantage of the regime meant it lacked the military manpower to avoid indiscriminate collateral damage and use of heavy weapons against urban neighbourhoods. Indeed, the regime may have deliberately used such violence to create refugees, a kind of ethnic cleansing meant to change the unfavourable demographic balance.

However, mass punishment of populations is likely to be counterproductive and this was certainly the case in Syria, where it provoked the militarization of the opposition. 
This is especially so in case of modern media wars, in which use of violence can be easily recorded with smart phones and held against the perpetrator. In the Syrian case, protestors uploaded smart phone images of regime violence to spread disaffection in Syria and invite foreign intervention. Indeed, from the beginning, the Syrian war was a propaganda war waged by disinformation on both sides (Joya 2012).

Three years after the Uprising began, the country had become divided between regime and opposition controlled regions, an egregious example of a failed state. Failed states are seen as a threat to international security, with at least one involved in $77 \%$ of international crises, 1990-2005 (Lamback and Debiel 2010: 161). The US/EU saw failed states as potential havens for terrorist groups and Piazza found instability in 19 Middle East and North Africa (MENA) states correlated with terrorist activity (Lambach and Diebel 2010). Indeed, the Syria conflict was widely seen as a breeding ground of terrorism. The vacuum of governance it created gave al-Qaida the opportunity to recover its declining fortunes and establish a major armed presence, with two alQaida franchises, Jahhat al-Nusra and Islamic State of Iraq and the Levant, rising in eastern Syria. They combined ideological motivation, the best fighters, access to natural resources (oil) and generous funding from patrons in the Gulf. One result was the emergence of a proto-state, the Islamic Caliphate, bridging Syria and Iraq. This was constructed as a threat in the West where governments feared that recruits to such jihadist groups from their own citizens would be radicalized and pose a threat when they returned home.

\section{SECURITIZATION, HUMAN SECURITY CRISIS AND HUMANITARIAN INTERVENTION}

\section{Security Referents: human security vs. state security}

The Syrian case carries relevance for debates in security studies over the referents of securitization. In the Syrian case, the human security view that the state can be a threat to its citizens' security is very well exemplified. The regime resorted to use of live fire against demonstrators, and when this stimulated rather than discouraged further protests, it escalated the use of violence. This escalation included the use of artillery and aerial bombing against urban populations, a selective blockage and starvation of rebel areas, and possibly the use of poison gas against opposition neighbourhoods.

Nevertheless, from the point of view of the regime and its supporters, the opposition were agents of foreign powers seeking to destabilize Syria. There is enough empirical evidence to give this view a modicum of credibility: the role played by external exiles and internet activists abroad, often Western funded, in provoking or escalating the Uprising was congruent with the regime's perceptions of conspiracy. It tarnished the indigenous opposition with the suspicion of treasonous dealings with foreign enemies, justifying the resort to repressive violence. Qatar's al-Jazeera deliberately encouraged revolt and Gulf funders provided copious amounts of arms and money to militarize the insurgency (Dickinson 2014). Syria became the battleground in a regional power struggle between rival states, with Turkey and the Gulf Cooperation Council (GCC) on one side and Iran on the other, each of which perceived the regional power balance and their own security at stake. Western and Gulf funding and arming of the opposition and 
the safe haven provided by Turkey for insurgents contributed to the militarization of the conflict as well. What was initially a human security issue became also an inter-state one.

\section{Intervention and 'Responsibility to Protect'}

The prospect of external intervention has loomed over the Syrian conflict from the start. Under the Responsibility to Protect (R2P) doctrine, sovereignty is contingent on states providing security for their populations and is forfeited when they become threats to it. Kerr (2008) argues that global intervention followed by peace building has contributed to a reduction in political violence. The Syrian case is widely seen by liberals and Syrian oppositionists as a failure of the responsibility to protect doctrine (Adams 2015). However, paradoxically, this very doctrine played a role in actually encouraging and increasing violent conflict in Syria.

From the outset, the possibility of external military intervention shaped both opposition and regime strategies. Anti-regime activists, including Syrian expatriates who were instrumental in initiating and internationalizing the Uprising, understood that they could not prevail against the regime without effective external constraints on its repressive options and some actively courted Western intervention. External activists told those on the ground, pointing to the Libya no-fly zone, that 'the international community won't sit and watch you be killed'. They claimed that another Hama massacre (referring to the violent repression of a 1982 Uprising) was not possible because 'Everything is being filmed on YouTube and there's a lot of international attention on the Middle East' (Seeyle 2011). There were reports that the opposition, particularly external Internet activists, systematically exaggerated bloodshed and found willing partners in the Western and Gulf-owned press (Joya 2012).

The previous intervention in Libya played a major role in encouraging protestors to escalate their confrontation with the regime on the expectation that Asad would need to restrain repression to avoid a similar intervention. Indeed, the regime tried to calibrate its violence within limits that would not trigger an international intervention, although over time this bar was steadily eroded. In mid-2011, it felt the need to quickly smash resistance so as not to lose control of territory that could be used to stage intervention as had happened in Libya. As it became evident that the West had no appetite for intervention the Syrian regime, not dependent on the West as were the Egyptian and Tunisian regimes, had little need to restrain its use of violence against opponents.

The West did move to diplomatically isolate and demonize the regime, withdrawing its ambassadors, and thereby forfeiting any potential for mediation in the conflict. It slapped sanctions on the regime meant to deprive it of oil revenue, which was indeed a key step in the debilitation of the Syrian state and of its capacity to provide basic services to the population, but not of the regime, which found alternative informal sources of revenue. This was yet another example of how blunt an instrument such sanctions can be (Bahrami and Parsi 2012). With Western politicians clamouring for military intervention and raising the spectre of the International Criminal Court (ICC), the regime inner core realized that there was no way back for them and that they had to stick together and do whatever was necessary to survive, including escalating from the 'security to a military solution.' Yet the threats against the regime by the West, while 
encouraging protestors, proved to be hollow and hence contributed to making a bad situation even worse.

\section{CONFLICT RESOLUTION AND DIPLOMACY}

There is considerable research on the conditions for political settlements in security studies, notably on negotiations (Zartman 1995) and on techniques (Track II diplomacy) to find common ground between the sides. One of the main propositions is that a 'hurting stalemate' provides a key condition for a political compromise (Zartman 2000).

In the Syrian case, efforts were made from the beginning to mediate a compromise resolution, notably by a moderate opposition group, the Arab League and by UN special envoys. This was rejected by both sides, however. According to participants in a workshop on prospects for a settlement, Syria has among the worst possible configurations for reaching a negotiated solution (Lynch 2013). To be sure, a hurting stalemate appeared to have been reached by at least the third year of the conflict as it became apparent that neither side could defeat the other (see. e.g. United Nations, 2012). However, as more and more blood was shed, powerful animosities were generated and neither side could imagine continued coexistence. The so-called 'commitment problem' is exaggerated in such scenarios: an opposition must insist on regime change rather than reform because it believes that the regime will renege on commitments as soon as the threat to its survival has passed (Fearon 2013). On the other hand, the regime could not make too many concessions under threat without looking weak and leading to defections and greater mobilization against it.

Each side continued to hope to win by further escalating the level of violence. To the extent victory seemed unrealistic, each wanted to first acquire the upper hand before going into negotiations. The highly fragmented opposition lacked leadership that could deliver the agreement of the whole opposition, particular the fighters on the ground, in the event a compromise was reached. There was an excessive number of 'veto players' and 'spoilers' who had no interest in a settlement, such as the jihadists and warlords thriving on the war economy. Each side was encouraged by external backers, but while these continued to provide their clients with enough support to keep fighting, it was not enough to defeat their opponent. A de facto partition soon emerged, with the front lines fairly stabilized. But partition was no solution in Syria, since communal groups are too intermingled, and, except among some Kurds, permanent division enjoyed little support as a solution.

At the time of writing, one side or the other might still collapse, notably if their external supporters withdraw the resources needed to continue. However, external players appear to be too invested in the outcome to accept defeat of their client. Even though $60-70 \%$ of recent civil wars resulted in the victory by one side or partition (Walters 2013), in the Syrian case, both sides would probably enjoy too little legitimacy to establish uncontested dominance, with the conflict likely to revive at a later point.

International diplomacy, according to Kerr (2008), is increasingly focusing on problems of violence in other societies. The UN Security Council is interpreting threats to international peace more broadly to encompass internal wars. Third party diplomacy is crucial in reaching negotiated settlements and the commitment obstacle can potentially 
be overcome through an external guarantee of a ceasefire. In the Syrian case, a precedent for international diplomatic co-operation seemed to be set by the agreement of the regime to give up its weapons of mass destruction, which it was accused of having used against its population. Russia's ability to deliver Asad into the agreement stopped the air strikes the US was preparing, which would have had incalculable consequences. In spite of this incipient great power diplomatic co-operation, the failure of Geneva II conference held in January 2014 to reach a negotiated political settlement to the Syrian crisis, is a case study in the limits of diplomacy.

The two great powers, the US and Russia, which were patrons of the two warring sides, sponsored negotiations between delegations from the regime and the opposition in exile. However, the parties to the conflict had to be pressured by their sponsors to attend and did so only to try to demonstrate the intransigence of the other side. The regime insisted on demonizing the opposition as terrorists; the opposition refused to countenance any solution that including a role for the incumbent president; had the opposition settled for less it would have been isolated from its constituency on the ground in Syria (Soukkary 2014).

To make it work, the regional backers of the two sides would have had to be brought into the process and pressured to stop their support for the conflict, but Iran was actually excluded from the conference and Saudi Arabia had no faith in it. Even though a settlement would have served the apparent shared interest of the two great powers in international stability, neither was willing to sufficiently lean on its client to force them to compromise. The US administration was unwilling to invest political capital, especially since the conflict, despite its risks to regional stability, had become an arena in which US enemies (Hezbollah, Al-Qaida) were bloodying each other. Russia saw defence of the Asad regime as a bulwark what it saw as the hegemonic expansive tendencies of the West (demonstrated, in its view, by the West's use of a Russianallowed UN humanitarian intervention resolution to engineer regime change in Libya).

\section{CONCLUSION}

Liberals and realists frequently divide over the wisdom of Western policies toward security crises in MENA. The Syrian crisis is no exception, where the debate over intervention has pitted the 'realist' advocates of caution, such as Stephen Walt (2014), against both the aggressive 'liberal imperialism' of the US neo-cons (Parmar 2009), and since the start of the Syrian uprising, the advocates of humanitarian intervention, inside and outside the Obama administration.

The hesitancy of the Obama Administration to intervene in Syria must in part be owing to an appreciation that regional security threats have often been the consequences of previous US interventions in the region. Thus, the threat from ISIS that became so salient in mid-2014 was in many ways a 'blowback' of Western policy. ISIS is a descendant of al-Qaida whose roots go back to Western support of Islamist radicals against the Soviet Union in Afghanistan, but which has risen most directly out of Islamist outrage at US use of Saudi bases to attack Iraq in the 1991 Gulf war (Atwan 2006). The US destruction of the Iraqi state in America's 2003 invasion made the country a magnet for al-Qaida, created a vacuum where it could operate, and also 
unleashed the Sunni-Shia sectarianization of the region on which jihadism has thrived and found further fertile ground in Syria.

The Syrian Uprising can itself be seen as an outcome of Western policies, at least in part. Western democracy promotion and the advocacy of the non-violent resistance paradigm showed itself, in MENA at least, to have a far greater potential to destabilize states than to promote democracy; it ignored both the conditions under which protest could be translated into democratic transition and the high costs, especially in fragmented societies, when it fails. Nor has Western liberalism appreciated how mechanisms such as R2P and the ICC may actually worsen human security because they encourage rebels, expecting external assistance, to uncompromisingly challenge regimes - and because regimes, once they start the use of violence, have no way back. The international normative climate paradoxically incentivized both sides to keep fighting in Syria, when a political solution might have had a better chance, had they been left to their own devices or external powers sought to mediate rather than take sides in the conflict. Seeming to promise intervention and then failing to do so in the Syrian case created the worse of all scenarios.

Finally, framing political struggles in terms of good and bad tends to debilitate the international diplomacy needed to cope with them. Thus, the refusal of the West to engage with both regime and opposition and invest the political capital in diplomatic brokerage of a power sharing settlement in Syria, manifest in the failure at Geneva II, opened the door to the Islamic State scenario, which drew the West into a conflict with much higher costs that might have been avoided under a different policy. By comparison to the dismal recent harvest of Western liberalism in MENA, "defensive realism' of the type promoted by Stephen Walt (2014), with its advocacy of caution and limited objectives, respect for sovereignty, and priority for diplomacy over military intervention, has garnered increased credibility.

\section{REFERENCES}

\section{Journal Articles:}

Chenoweth, Erica and Maria J. Stephan (2008), 'Why Civil Resistance Works: The Strategic Logic of Nonviolent Conflict, International Security, 33:1, 2008, 7-44.

Goldsmith, Leon (2011), 'Syria's Alawites and the Politics of Sectarian Insecurity, A Khaldounian Perspective, Ortadoğu Etütleri, Volume 3, No 1, July, pp. 46-49.

Hinnebusch, Raymond (2012) 'Syria: from Authoritarian Upgrading to Revolution?' International Affairs, January.

Joya, Angela (2012) 'Syria and the Arab Spring: The Evolution of the Conflict and the Role of Domestic External and Factors', Ortadoğu Etütleri, 4, no. 1 (July 2012), $40-3$.

Inderjeet Parma (2009) 'Foreign policy fusion: Liberal interventionists, conservative nationalists and neoconservatives — the new alliance dominating the US foreign policy establishment.' International Politics, 46, 177-209 
Posen, Barry (1993) 'The Security Dilemma and Ethnic Conflict', Survival, 35, no. 1 (Spring).

\section{Monographs}

Atwan, Abdel Bari, (2006) The Secret History of al Qaeda, Berkeley, CA: University of California Press.

Ayoob (1995) The Third World Security Predicament: State Making, regional Conflict and the International System, Boulder, CO: Lynne Rienner Publishers.

Fromkin, David (1989), A Peace to End all Peace: Creating the Modern Middle East: 1914-1922, London and NY: Penguin Press.

Hinnebusch, Raymond (2001) Syria: revolution from above, London: Routledge, 2001 .

Kaldor, Mary (1999). New \& Old Wars: Organized Violence in a Global Era,' Cambridge: Polity Press.

Lynch, Marc (2103), The Political Science of Syria's War, POMPES Briefing, Washington, D.C.: George Washington University,

O'Donnell, Guillermo and Philippe Schmitter (1986), Transitions from Authoritarian Rule: Tentative Conclusions about Uncertain Democracies, Part 4 (Baltimore, MD: Johns Hopkins University Press.

Zartman, I. William (1995), Elusive Peace: Negotiating an end to civil wars, Washington, D.C: Brookings Institution

\section{Edited Volume}

Dunn Cavelty and Victor Mauer, eds.(2010), Handbook of Security Studies, London and NY: Routledge.

Williams, Paul D., ed., (2008), Security Studies: An Introduction, London and New York: Routledge.

\section{Chapters in Edited Volumes:}

Fearon, James (2013) "Syria's Civil War," in Marc Lynch, ed. The Political Science of Syria's War, Project on Middle East Political Science, POMEPS Studies No 5 pp. 13-18.

Kaufman, Stuart, (2008) "Ethnic Conflict" in in Paul Williams, Security Studies: An Introduction, London and NY: Routledge, pp. 201-15

Kerr, Pauline (2008) 'Human Security and Diplomacy,' in Handbook of Security Studies, eds. Myriam Dunn Cavelty and Victor Mauer, London and NY: Routledge, pp. $115-26$ 
Lambach, Daniel (2010) and Tobias Debiel, 'State Failure and State Building,' in Handbook of Security Studies, pp. 159-68.

Spears, Joanna (2008) 'Insurgency and Counterinsurgency,' Paul Williams, Security Studies: an introduction, London and NY: Routledge, pp. 389-405.

Tilly, Charles (1985) 'War Making and State Making as Organized Crime.' In: Evans, PJ, Rueschemeyer D, and Skocpol T (eds) Bringing the state back in. Cambridge: Cambridge University Press.

Walter, Barbara (2013), 'The Four Things We Know About How Civil Was End (and what it tells us about Syria)' in Marc Lynch, ed. The Political Science of Syria's War, Project on Middle East Political Science, POMEPS Studies No 5.

Zartman, (2000) "Ripeness: The Hurting Stalemate and Beyond," in International Conflict Resolution After the Cold War, eds, Committee on International Conflict Resolution, Washington, D.C.: National Academies Press, pp 225-50.

\section{Online Sources}

Adams, Simon (2015), "Failure to Protect: Syria and the UN Security Council," Global Centre for the Responsibility to Protect, Occasional Papers Series No 5, March, 2015, http://www.globalr2p.org/media/files/syriapaper_final.pdf

Bahrami, Natasha and Trita Parsi (2012), 'Blunt Instrument: Sanctions Don't Promote Democratic Change' Boston Review, February 6, http://bostonreview.net/natash-bahrami-trita-parsi-iran-sanctions

Dickinson, Elizabeth (2014), “The Case against Qatar," Foreignpolicy.com, http://www.foreignpolicy.com/articles/2014/09/30/the case against q atar_funding_extremists_salafi_syria_uae_jihad_muslim_brotherhood_ taliban

Falk, Richard, 'Syria: What To Do Now,' Global Justice in the $21^{\text {st }}$ Century, https://richardfalk.wordpress.com/2014/02/26/syria-what-to-do-now/

Harling, Peter (2011) 'Syria's Race against the Clock', Foreign Policy, 11 Apr, http://mideast.foreignpolicy.com/posts/2011/04/11/syrias race_against the cl ock

Kaldor, Mary (2013) 'What to do in Syria?'10 September, OpenDemocracyhttps://www.opendemocracy.net/mary-kaldor/what-to-do-in- syria

Mandour, Maged (2013), 'Beyond Civil Resistance: The Case of Syria', openDemocracy, 26 Oct, www.opendemocracy.net/arab-awakening/maged mandour/beyond-civil-resistance-case-of-syria

Schanzer, Jonathan and Tahiroglu, Merve (2014), 'Bordering on Terrorism: Turkey’s 
Syria Policy and the rise of the Islamic State,' Washington, D.C.: Foundation for Defense of Democracies.

Seelye, Kate (2011) 'Syria Unrest 'Cannot Be Contained', The Daily Beast, 28 Mar., www.thedailybeast.com/articles/2011/03/28/syria-unrest-cannot-be- containeddissidents-say.html.

Al-Soukkary, Ahmed Magdy (2014) 'Negotiating the Syrian Crisis,' http://www.transconflict.com/2014/03/negotiating-syrian-crisis-getting-yes-still-far203/

United Nations (2012), "Final communiqué of the Action Group for Syria - Geneva, 30 June 2012", http://www.un.org/News/dh/infocus/Syria/FinalCommuniqueActionGroupforSyria.p $\underline{\mathrm{df}}$

Walt, Steven (2014) Democracy, Freedom, and Apple Pie Aren't a Foreign Policy, http://www.foreignpolicy.com/articles/2014/07/01/american_values_are to blame f or_the_worlds_chaos_democracy_human_rights_ukraine_iraq 